\title{
Mortality risk of black women and white women with invasive breast cancer by hormone receptors, HER2, and p53 status
}

Huiyan Ma ${ }^{1 *}$, Yani Lu' ${ }^{1}$ Kathleen E Malone ${ }^{2}$, Polly A Marchbanks ${ }^{3}$, Dennis M Deapen ${ }^{4}$, Robert Spirtas ${ }^{6}$, Ronald T Burkman ${ }^{7}$, Brian L Strom ${ }^{8}$, Jill A McDonald ${ }^{3}$, Suzanne G Folger ${ }^{3}$, Michael S Simon ${ }^{9}$, Jane Sullivan-Halley ${ }^{1}$, Michael F Press ${ }^{5}$ and Leslie Bernstein ${ }^{1}$

\begin{abstract}
Background: Black women are more likely than white women to have an aggressive subtype of breast cancer that is associated with higher mortality and this may contribute to the observed black-white difference in mortality. However, few studies have investigated the black-white disparity in mortality risk stratified by breast cancer subtype, defined by estrogen receptor (ER), progesterone receptor (PR) and human epidermal growth factor receptor 2 (HER2) status. Furthermore, it is not known whether additional consideration of p53 protein status influences black-white differences in mortality risk observed when considering subtypes defined by ER, PR and HER2 status.

Methods: Four biomarkers were assessed by immunohistochemistry in paraffin-embedded breast tumor tissue from 1,204 (523 black, 681 white) women with invasive breast cancer, aged 35-64 years at diagnosis, who accrued a median of 10 years' follow-up. Multivariable Cox proportional hazards regression models were fit to assess subtype-specific black-white differences in mortality risk.

Results: No black-white differences in mortality risk were observed for women with triple negative (ER-negative [ER-], PR-, and HER2-) subtype. However, older (50-64 years) black women had greater overall mortality risk than older white women if they had been diagnosed with luminal A (ER-positive [ER+] or PR+ plus HER2-) breast cancer (all-cause hazard ratio, HR, 1.88; 95\% confidence interval, $\mathrm{Cl}, 1.18$ to 2.99; breast cancer-specific HR, 1.51; 95\% Cl, 0.83 to 2.74). This black-white difference among older women was further confined to those with luminal A/p53-tumors (all-cause HR, 2.22; 95\% Cl, 1.30 to 3.79; breast cancer-specific HR, 1.89; 95\% Cl, 0.93 to 3.86). Tests for homogeneity of race-specific HRs comparing luminal A to triple negative subtype and luminal A/p53- to luminal A/p53+ subtype did not achieve statistical significance, although statistical power was limited.
\end{abstract}

Conclusions: Our findings suggest that the subtype-specific black-white difference in mortality risk occurs mainly among older women diagnosed with luminal A/p53- breast cancer, which is most likely treatable. These results further suggest that factors other than subtype may be relatively more important in explaining the increased mortality risk seen in older black women.

Keywords: Breast cancer, Mortality, Racial disparity, Triple negative, Luminal A, ER, PR, HER2, p53

\footnotetext{
*Correspondence: hma@coh.org

${ }^{1}$ Division of Cancer Etiology, Department of Population Sciences, Beckman Research Institute, City of Hope, Duarte, CA 91010, USA

Full list of author information is available at the end of the article
} 


\section{Background}

Although mortality following breast cancer diagnosis has decreased substantially in the United States over the last three decades, a large black-white difference remains. Black women have higher risk of death after breast cancer diagnosis than white women [1,2] and are more likely than white women to have an aggressive subtype of breast cancer that is associated with a higher mortality [3], which could contribute to the observed black-white mortality difference. However, only a few studies have investigated the black-white disparity in mortality risk by breast cancer subtype as defined by estrogen receptor (ER), progesterone receptor (PR), and human epidermal growth factor receptor 2 (HER2) status [4-7]. Furthermore, little is known whether additional consideration of $\mathrm{p} 53$ protein status has any influence on black-white differences in mortality risk within subtype strata.

Breast cancer is a heterogeneous disease; its subtypes have been classified as triple negative (TN) (ER-negative [ER-], PR-, and HER2-), luminal A (ER-positive [ER+] or $\mathrm{PR}+$ plus HER2-), luminal B (ER+ or PR+ plus HER2+), and HER2-enriched (ER-/PR-/HER2+) subtype [8-16]. Gene expression studies using cDNA microarray technology show that TN breast cancers are often characterized by a "basal-like" molecular profile [17], characteristic of the basal epithelial cell layer, including high level expression of HER1 and/or genes encoding cytokeratins 5/6 [3]. Because cDNA microarray technology is not yet available clinically for identifying basal-like subtype, the TN subtype has become a commonly used proxy for the "basal-like" subtype in clinical and epidemiologic studies, despite the fact that TN subtype and basal-like subtype are discordant in $20-30 \%$ of cases $[17,18]$.

TN breast tumors, which account for 10-25\% of all invasive breast cancers $[19,20]$, have poorer prognosis than luminal $\mathrm{A}$, the most common subtype $[8,9,13]$. While $\mathrm{ER}+$ breast cancers respond favorably to anti-estrogen therapy and HER2+ breast cancers respond favorably to trastuzumab therapy $[20,21]$, no targeted therapies currently exist for TN breast cancer. Studies have consistently shown that TN breast cancers comprise a higher proportion of breast cancers in black women than white women [3,4,11,22-24]. However, little research has been done examining the extent to which black-white mortality differences exist within each specific breast cancer subtype. Two studies reported that the black-white differences in all-cause mortality [4] and breast cancer-specific mortality [6] were limited to the TN subtype. A third study reported that the crude all-cause mortality risk was greater among black women than white women irrespective of the subtypes defined by ER, PR, and HER2 status [7]. The Carolina Breast Cancer Study found instead, that the black-white differences in breast cancer-specific mortality occurred among women diagnosed with luminal A breast cancer, but not among those diagnosed with basal-like breast cancer [5].

p53 is a tumor suppressor gene, which encodes the p53 protein $[25,26]$. p53 protein is involved in gene transcription, DNA synthesis/repair, genomic plasticity and programmed cell death [27]. Mutations in $p 53$ have been identified in approximately $15-35 \%$ of breast cancers [28-30] and are associated with resistance to chemotherapy, radiotherapy [31] and poor prognosis [32]. p53 mutations occur more frequently in breast cancers of black women than in those of white women [33] and these mutations are more common in breast cancers that are ER-/PR- [34], TN [35], or basal-like [3,34] than in breast cancers that are ER+ or PR+. p53 mutations, especially missense mutations, are highly correlated with the p53 protein overexpression in tumor tissue [36,37]. One epidemiologic study examined the effect of p53 status on allcause morality for African American (AA) women and non-AA women, respectively, and found that having a p53+ tumor adversely affected prognosis among AA women but not non-AA women after controlling for multiple variables including the individual status of ER, PR and HER2 or subtype as determined by 3 or 5 marker panels. No analyses were reported on whether the overexpression status of p53 protein impacted the black-white disparity in mortality within strata of breast cancer subtype [7].

We have previously shown that white women with invasive breast cancer participating in the Women's Contraceptive and Reproductive Experiences (CARE) Study who had higher body mass index (BMI) had higher mortality risk than those with a normal (not overweight) BMI; but this association did not hold for black women [38]. Here, we determine the extent to which black-white differences in breast cancer-specific and all-cause mortality differ for TN, luminal A, luminal B, and HER2-enriched breast cancers in a substudy conducted at two participating study sites where tumor tissue was collected. We then assess whether any black-white mortality differences that existed for the two common breast cancer subtypes, TN and luminal $\mathrm{A}$, are affected by $\mathrm{p} 53$ protein expression status.

\section{Methods}

\section{Study population and data collection}

The participants for this analysis are women from two study sites, Detroit and Los Angeles (LA), participating in the Women's CARE Study, a population-based casecontrol study designed to examine risk factors for invasive breast cancer among US-born black women and white women including those of Hispanic ethnicity [39]. The Women's CARE Study selected a stratified (by age group) random sample of women aged 35 to 64 years who were newly diagnosed with histologically confirmed incident invasive breast cancer (International Classification of Diseases for Oncology codes C50.0-C50.9) 
between July 1994 and April 1998. Black women were oversampled to maximize their numbers in the study, and white women were sampled to provide approximately equal numbers of women in each 5-year age category (from 35 to 64 years). Race was based on participants' self-identification. From the two study sites, the Women's CARE Study recruited 1,921 breast cancer patients (Detroit: 679, LA: 1,242). These two study sites were selected to collect tumor tissue samples based on representative case participants in the Women's CARE Study and the ability to obtain tumor tissue samples. All participants provided written informed consent. The study protocol was approved by the Institutional Review Boards at the University of Southern California (IRB\#: HS-923048), the Karmanos Comprehensive Cancer Center at Wayne State University (IRB\#: WSU HIC\# H 04-09-96 (M05)-FB), the Centers for Disease Control and Prevention (IRB\#: 1862), and the City of Hope (IRB\#: 08098).

\section{Assessment of biomarkers}

Paraffin-embedded tumor blocks were obtained from pathology laboratories where diagnoses were made for 1,333 participating breast cancer cases (Detroit: 414, LA: 919), approximately $80 \%$ of those requested. Tumor blocks were carefully reviewed and evaluated in the centralized pathology laboratory of Dr. Michael F. Press at the University of Southern California.

We excluded 127 case samples because the tumor blocks contained only carcinoma in situ $(\mathrm{n}=56)$ or no tumor tissue $(\mathrm{n}=46)$; had insufficient tissue for assay $(\mathrm{n}=3)$; had other problems $(n=14)$; or only hematoxlin-and-eosin stained tissue sections were received $(n=8)$. The expression of ER, PR, HER2, and p53 was determined for the remaining 1,206 samples (Detroit: 367, LA: 839).

The expression of ER and PR was determined using previously published immunohistochemistry (IHC) methods $[40,41]$. Immunostaining results for ER and PR expression were interpreted in a blind fashion and scored semiquantitatively on the basis of the visually estimated percentage of positively stained tumor cell nuclei. At least 100 tumor cells were examined for each specimen; $\geq 1 \%$ immunostained tumor cell nuclei was considered positive for ER and PR status [42].

HER2 expression was determined by IHC using the $10 \mathrm{H} 8$ monoclonal antibody $[43,44]$ to assess HER2 membrane protein immunostaining. No (0) or weak (1+) membrane immunostaining was considered low HER2 expression (HER2-). Moderate (2+) or strong membrane immunostaining $(3+)$ was considered HER2 overexpression (HER2+) based on previous validation results from the same pathology laboratory, indicating over $90 \%$ specimen samples scored as $2+(80.6 \%)$ or $3+(98.9 \%)$ by $10 \mathrm{H} 8-\mathrm{IHC}$ showed HER-2 gene amplification by fluorescent in situ hybridization (FISH) analysis [43].
The expression of p53 protein was determined by IHC using the monoclonal mouse antibodies DO7 (Oncogene Science, Inc. Cambridge, MA) and BP 53-12-1 (Biogenex) to measure p53 nuclear protein immunostaining. Based on findings from previous studies, comparing p53 mutations in exons $2-11$ with p53 protein expression levels $[37,45], \geq 10 \%$ nuclear staining for $\mathrm{p} 53$ protein was deemed positive [46].

\section{Tumor characteristics from SEER}

The Women's CARE Study collected tumor stage, tumor histologic grade, and other tumor characteristics. We excluded two more women because they were missing information on tumor stage, resulting in the final sample size of 1,204 (523 black, 681 white) women for the analyses.

\section{Vital status follow-up}

Women were followed up annually for vital status, date of death and cause of death using standard SEER followup procedures. Women from Detroit were followed through December 31, 2004; follow-up extended until December 31, 2007 in LA.

\section{Statistical analyses}

We used Pearson Chi-squared tests to compare frequency distributions of categorical variables between black women and white women.

Adjusted estimates of the hazard ratio (HR) of death, a measure of relative risk, and its $95 \%$ confidence interval (CI), comparing black women to white women, were calculated for each breast cancer subtype of interest using Cox proportional hazards regression models [47]. Two Cox proportional hazards regression models were applied. In Model 1, we used age (in days) at diagnosis and at death or end of follow-up as the time scale, and stratified by single years of age at diagnosis and adjusted for study site. In the analyses of breast cancer-specific mortality (International Classification of Diseases codes ICD9-174, ICD10-C50), women who died from other causes were censored on their dates of death. In Model 2 , we additionally adjusted for tumor stage. Tumor grade was not included in Model 2 since it did not cause more than a $10 \%$ change in any of the risk estimates. We conducted the analyses for all women and separately for two age groups (younger: 35-49, older: 50-64 years at diagnosis). Homogeneity of race-specific HRs across different subtypes was evaluated using a $\mathrm{Z}$ test of the differences in adjusted log race-specific HRs divided by the square root of the sum of the variances of the two racespecific log HRs [48]. Since 9 black women and 73 white women reported Hispanic ethnicity, we repeated all the analyses after excluding these 82 women. Our results remained similar. Therefore, we present the results based on the analyses of all participants. 
Kaplan-Meier breast cancer-specific curves [49] were constructed to demonstrate black-white survival differences observed in older women with luminal A invasive breast cancer.

We considered a two-sided $P$ value less than 0.05 as statistically significant when testing for homogeneity of HRs across subtypes of breast cancer. All statistical analyses were performed using SAS version 9.2 software (SAS Institute, Cary, NC).

\section{Results}

\section{Study population characteristics}

During a median follow-up of 10 years (9.9 years and 10.0 years for black women and white women, respectively), 272 (141 black and 131 white) women died specifically from breast cancer and 63 (39 black and 24 white) women died from other causes. Compared with white women, black women were more likely to be diagnosed with ER-, PR-, TN, p53+, non-localized, or higher grade tumors (all $P<0.001$, Table 1 ). The frequency distribution of HER2 in black women was not statistically significantly different from that of white women overall $(P=0.16)$ or in younger women 35 to 49 years of age $(P=0.98)$, whereas older black women 50 to 64 years of age were more likely to be diagnosed with HER2 + tumors than white women in the same age group $(P=0.04)$.

\section{Black-white difference in breast cancer-specific mortality}

After controlling for age at diagnosis and study site, black-white differences for breast cancer-specific mortality risk were observed among women diagnosed with luminal A breast cancer (HR, 1.52; 95\% CI, 1.01 to 2.28), but not among those diagnosed with $\mathrm{TN}$ breast cancer (HR, 1.21; 95\% CI, 0.81 to 1.83 , Table 2 ). The magnitude of race-specific HR estimates for other subtypes (luminal $\mathrm{B}$ and HER2-enriched) was at least as great as that for luminal A but due to small numbers for these subtypes (and thus few deaths), 95\% CIs included 1.0. Analyses by age group at diagnosis (35-49 versus 50-64 years) showed that the black-white differences in breast cancer-specific mortality predominately existed among older women with luminal A tumors (HR, 2.07; 95\% CI, 1.16 to 3.70), but not in younger women diagnosed with luminal A tumor or among women diagnosed with $\mathrm{TN}$ tumor regardless of age group. When older women were further stratified by p53 protein expression, the black-white difference in mortality risk was observed among those with luminal $\mathrm{A}$ tumors that were p53- (HR, 2.53; 95\% CI, 1.27 to 5.04, Figure 1).

Since black women are more likely than white women to be diagnosed with advanced stages of breast cancer, which is associated with a higher risk of mortality [50], we additionally controlled for tumor stage in our analysis. Then, the observed black-white differences in breast cancer-specific mortality were attenuated. The HR for black-white difference in older women diagnosed with luminal A/p53- breast cancer decreased from 2.53 ( $95 \%$ CI, 1.27 to 5.04 ) to 1.89 (95\% CI, 0.93 to 3.86 ).

\section{Black-white difference in all-cause mortality}

Similar to the results for breast cancer-specific mortality, the black-white difference in all-cause mortality risk after controlling for age at diagnosis and study site was observed among older women with luminal A tumors (HR, 2.21; 95\% CI, 1.40 to 3.47, Table 3), but not among younger women diagnosed with luminal A tumor or among women diagnosed with $\mathrm{TN}$ tumor regardless of age group. When further stratified by p53 protein expression status, the black-white difference in all-cause mortality was observed only among older women diagnosed with luminal A/p53- breast cancer (HR, 2.49; 95\% CI, 1.47 to 4.22 ).

The observed black-white differences in all-cause mortality were also decreased after additionally controlling for tumor stage, but the magnitude of the decrease appeared smaller than that observed for breast cancerspecific mortality. The HR for black-white difference in all-cause mortality in older women diagnosed with luminal A/p53- breast cancer decreased from 2.49 (95\% CI, 1.47 to 4.22 ) to 2.22 (95\% CI, 1.30 to 3.79 ).

\section{Test for homogeneity across subtypes}

Although black-white differences in mortality after breast cancer diagnosis were observed only among older women diagnosed with luminal $\mathrm{A}$ and luminal A/p53subtype, no tests for homogeneity of race-specific HRs across subtypes achieved statistical significance (results not shown).

\section{Discussion}

In the current analysis of 1,204 women 35 to 64 years of age, with a median follow-up of 10 years, we did not observe any statistically significant black-white differences in cancer-specific or all-cause mortality among women diagnosed with TN subtype. We did, however, find that black women had statistically significant greater allcause mortality risk than white women among those ages 50-64 years who were diagnosed with luminal A tumors, and more specifically among those diagnosed with luminal A/p53- breast cancer. However, no tests for homogeneity of race-specific HRs comparing luminal A to $\mathrm{TN}$ subtype and luminal A/p53- to luminal A/p53+ subtype achieved statistical significance.

The results from four previous epidemiologic studies that compared mortality risk or survival in black and white women diagnosed with luminal A or TN or basallike subtype are inconsistent [4-7]. One study with 11 to 13 years of follow-up of 476 (116 black, 360 white) 
Table 1 Percent distribution of selected characteristics at diagnosis in 1,204 women with invasive breast cancer

\begin{tabular}{|c|c|c|c|c|c|c|c|c|c|}
\hline & \multirow{2}{*}{\multicolumn{3}{|c|}{ All women }} & \multirow{2}{*}{\multicolumn{3}{|c|}{$\begin{array}{c}\text { Younger women } \\
\text { (ages 35-49 y) }\end{array}$}} & \multirow{2}{*}{\multicolumn{3}{|c|}{$\begin{array}{l}\text { Older women } \\
\text { (ages 50-64 y) }\end{array}$}} \\
\hline & & & & & & & & & \\
\hline & \multirow{2}{*}{$\begin{array}{l}\text { White } \\
n=681\end{array}$} & \multirow{2}{*}{$\begin{array}{l}\text { Black } \\
n=523\end{array}$} & \multirow[t]{2}{*}{$P^{\mathrm{a}}$} & White & Black & $P^{a}$ & White & Black & $P^{a}$ \\
\hline & & & & $n=345$ & $n=272$ & & $n=336$ & $n=251$ & \\
\hline Study site & & & 0.01 & & & 0.07 & & & 0.09 \\
\hline Los Angeles & 66.7 & 73.2 & & 64.9 & 71.7 & & 68.5 & 74.9 & \\
\hline Detroit & 33.3 & 26.8 & & 35.1 & 28.3 & & 31.6 & 25.1 & \\
\hline Age at diagnosis, years & & & 0.004 & & & $<0.001$ & & & \\
\hline $35-39$ & 21.4 & 14.2 & & 42.3 & 27.2 & & - & - & \\
\hline $40-44$ & 15.9 & 19.5 & & 31.3 & 37.5 & & - & - & \\
\hline $45-49$ & 13.4 & 18.4 & & 26.4 & 35.3 & & - & - & \\
\hline $50-54$ & 18.7 & 17.6 & & - & - & & 37.8 & 36.7 & 0.42 \\
\hline $55-59$ & 14.5 & 16.4 & & & - & & 29.5 & 34.3 & \\
\hline $60-64$ & 16.2 & 14.0 & & - & - & & 32.7 & 29.1 & \\
\hline ER status & & & $<0.001$ & & & 0.05 & & & $<0.001$ \\
\hline ER- & 36.9 & 48.8 & & 46.4 & 54.4 & & 27.1 & 42.6 & \\
\hline ER+ & 63.1 & 51.2 & & 53.6 & 45.6 & & 72.9 & 57.4 & \\
\hline PR status & & & $<0.001$ & & & $<0.001$ & & & $<0.001$ \\
\hline PR- & 38.5 & 52.4 & & 42.6 & 54.0 & & 34.2 & 50.6 & \\
\hline PR+ & 61.5 & 47.6 & & 57.4 & 46.0 & & 65.8 & 49.4 & \\
\hline HER2 status & & & 0.16 & & & 0.98 & & & 0.04 \\
\hline HER2- & 83.3 & 80.1 & & 81.2 & 81.3 & & 85.4 & 78.9 & \\
\hline HER2+ & 16.7 & 19.9 & & 18.8 & 18.7 & & 14.6 & 21.1 & \\
\hline Subtypes defined by ER/PR/HER2 & & & $<0.001$ & & & 0.12 & & & $<0.001$ \\
\hline TN & 23.8 & 33.5 & & 30.4 & 39.0 & & 17.0 & 27.5 & \\
\hline Luminal A & 59.5 & 46.7 & & 50.7 & 42.3 & & 68.5 & 51.4 & \\
\hline Luminal B & 9.8 & 10.3 & & 11.0 & 9.9 & & 8.6 & 10.8 & \\
\hline HER2-enriched & 6.9 & 9.6 & & 7.8 & 8.8 & & 6.0 & 10.4 & \\
\hline p53 status & & & $<0.001$ & & & & & & 0.003 \\
\hline p53- & 77.0 & 65.8 & & 72.5 & 61.0 & 0.003 & 81.6 & 70.9 & \\
\hline p53+ & 23.0 & 34.2 & & 27.5 & 39.0 & & 18.4 & 29.1 & \\
\hline Subtypes defined by ER/PR/HER2/p53 & & & $<0.001$ & & & 0.03 & & & $<0.001$ \\
\hline TN/p53- & 14.4 & 16.6 & & 18.0 & 18.8 & & 10.7 & 14.3 & \\
\hline TN/p53+ & 9.4 & 16.8 & & 12.5 & 20.2 & & 6.3 & 13.2 & \\
\hline Luminal A/p53- & 49.9 & 37.7 & & 41.5 & 31.3 & & 58.6 & 44.6 & \\
\hline Luminal A/p53+ & 9.5 & 9.0 & & 9.3 & 11.0 & & 9.8 & 6.8 & \\
\hline Luminal B/p53- & 8.1 & 6.0 & & 8.4 & 5.2 & & 7.7 & 6.8 & \\
\hline Luminal B/p53+ & 1.8 & 4.4 & & 2.6 & 4.8 & & 0.9 & 4.0 & \\
\hline HER2-enriched/p53- & 4.6 & 5.5 & & 4.6 & 5.9 & & 4.5 & 5.2 & \\
\hline HER2-enriched/p53+ & 2.4 & 4.0 & & 3.2 & 2.9 & & 1.5 & 5.2 & \\
\hline Stage & & & $<0.001$ & & & 0.007 & & & 0.001 \\
\hline Localized & 63.1 & 51.1 & & 56.5 & 45.6 & & 69.9 & 57.0 & \\
\hline Non-localized & 36.9 & 49.0 & & 43.5 & 54.4 & & 30.1 & 43.0 & \\
\hline Grade & & & $<0.001$ & & & 0.006 & & & $<0.001$ \\
\hline Low & 12.5 & 8.6 & & 9.6 & 6.6 & & 15.5 & 10.8 & \\
\hline Intermediate & 63.1 & 53.0 & & 58.6 & 49.3 & & 67.9 & 57.0 & \\
\hline High & 24.4 & 38.4 & & 31.9 & 44.1 & & 16.7 & 32.3 & \\
\hline
\end{tabular}


Table 2 Adjusted HRs of breast cancer-specific mortality associated with race (black women vs. white women)

\begin{tabular}{|c|c|c|c|c|c|c|c|c|}
\hline & \multicolumn{2}{|c|}{ White } & \multicolumn{2}{|c|}{ Black } & \multicolumn{2}{|c|}{ Model $1^{\mathrm{a}}$} & \multicolumn{2}{|c|}{ Model $2^{\mathrm{a}, \mathrm{b}}$} \\
\hline & Person-years & Death (No.) & Person-years & Death (No.) & $\mathrm{HR}$ & $95 \% \mathrm{Cl}$ & $\mathrm{HR}$ & $95 \% \mathrm{Cl}$ \\
\hline All women & 6246 & 131 & 4471 & 141 & 1.54 & 1.21 to 1.97 & 1.26 & 0.99 to 1.62 \\
\hline \multicolumn{9}{|l|}{ Subtypes defined by ER/PR/HER2 } \\
\hline TN & 1341 & 46 & 1381 & 57 & 1.21 & 0.81 to 1.83 & 1.08 & 0.71 to 1.64 \\
\hline Luminal A & 3853 & 56 & 2235 & 47 & 1.52 & 1.01 to 2.28 & 1.23 & 0.81 to 1.86 \\
\hline Luminal B & 643 & 16 & 481 & 14 & 1.67 & 0.67 to 4.19 & 0.98 & 0.27 to 3.58 \\
\hline HER2-enriched & 408 & 13 & 375 & 23 & 2.27 & 0.87 to 5.93 & 1.95 & 0.71 to 5.37 \\
\hline \multicolumn{9}{|l|}{ Subtypes defined by ER/PR/HER2/p53 } \\
\hline TN/p53- & 825 & 24 & 664 & 30 & 1.38 & 0.76 to 2.51 & 1.32 & 0.70 to 2.47 \\
\hline TN/p53+ & 516 & 22 & 717 & 27 & 1.04 & 0.56 to 1.93 & 1.03 & 0.55 to 1.95 \\
\hline Luminal A/p53- & 3262 & 39 & 1814 & 33 & 1.50 & 0.92 to 2.44 & 1.22 & 0.74 to 2.04 \\
\hline Luminal A/p53+ & 591 & 17 & 421 & 14 & 1.10 & 0.40 to 2.97 & 0.81 & 0.28 to 2.39 \\
\hline Younger women (ages 35-49 yrs) & 3066 & 83 & 2248 & 84 & 1.45 & 1.06 to 1.99 & 1.21 & 0.87 to 1.66 \\
\hline \multicolumn{9}{|l|}{ Subtypes defined by ER/PR/HER2 } \\
\hline TN & 861 & 33 & 785 & 39 & 1.30 & 0.80 to 2.12 & 1.11 & 0.67 to 1.84 \\
\hline Luminal A & 1623 & 31 & 1069 & 22 & 1.16 & 0.65 to 2.05 & 1.01 & 0.56 to 1.80 \\
\hline \multicolumn{9}{|l|}{ Subtypes defined by ER/PR/HER2/p53 } \\
\hline TN/p53- & 513 & 17 & 372 & 19 & 1.38 & 0.67 to 2.85 & 1.39 & 0.66 to 2.95 \\
\hline TN/p53+ & 349 & 16 & 413 & 20 & 1.14 & 0.56 to 2.35 & 1.07 & 0.51 to 2.25 \\
\hline Luminal A/p53- & 1329 & 23 & 792 & 12 & 0.86 & 0.41 to 1.80 & 0.77 & 0.36 to 1.63 \\
\hline Luminal A/p53+ & 294 & 8 & 277 & 10 & 1.04 & 0.23 to 4.63 & 0.80 & 0.17 to 3.72 \\
\hline Older women (ages 50-64 yrs) & 3181 & 48 & 2223 & 57 & 1.71 & 1.16 to 2.53 & 1.38 & 0.93 to 2.04 \\
\hline \multicolumn{9}{|l|}{ Subtypes defined by ER/PR/HER2 } \\
\hline $\mathrm{TN}$ & 480 & 13 & 596 & 18 & 1.00 & 0.47 to 2.10 & 1.03 & 0.48 to 2.20 \\
\hline Luminal A & 2231 & 25 & 1167 & 25 & 2.07 & 1.16 to 3.70 & 1.51 & 0.83 to 2.74 \\
\hline \multicolumn{9}{|l|}{ Subtypes defined by ER/PR/HER2/p53 } \\
\hline TN/p53- & 313 & 7 & 292 & 11 & 1.56 & 0.52 to 4.67 & 1.34 & 0.41 to 4.37 \\
\hline TN/p53+ & 167 & 6 & 304 & 7 & 0.79 & 0.23 to 2.71 & 0.87 & 0.24 to 3.14 \\
\hline Luminal A/p53- & 1934 & 16 & 1022 & 21 & 2.53 & 1.27 to 5.04 & 1.89 & 0.93 to 3.86 \\
\hline Luminal A/p53+ & 297 & 9 & 144 & 4 & 1.16 & 0.31 to 4.35 & 0.90 & 0.15 to 5.48 \\
\hline
\end{tabular}

HRs are from multivariable Cox proportional hazards regression models using age (in days) at diagnosis and at death or end of follow-up as the time scale and stratified by single years of age at diagnosis. ${ }^{a}$ Adjusted for study site. ${ }^{b}$ Additionally adjusted for tumor stage. Abbreviations: $\mathrm{HR}$, hazard ratio; $\mathrm{Cl}$, confidence interval. ER, estrogen receptor; PR, progesterone receptor; HER, human epidermal growth factor receptor; TN, triple negative. Note: TN = ER-/PR-/HER2-, Luminal $\mathrm{A}=\mathrm{ER}+$ or PR+ plus HER2-, Luminal $\mathrm{B}=\mathrm{ER}+$ or PR+ plus HER2+, HER2-enriched = ER-/PR-/HER2+.

Atlanta women diagnosed between 1990 and 1992 with invasive breast cancer at ages 20-54 years found that risk of all-cause mortality was greater among black women than among white women for both luminal A cancer (unadjusted HR, 1.6; 95\% CI, 1.1 to 2.4 ) and TN breast cancer (unadjusted HR, 2.1; 95\% CI, 1.3 to 3.3). The racial difference disappeared for luminal A breast cancer after adjustment for age, stage, and grade (adjusted HR, 1.1 ; $95 \%$ CI, 0.7 to 1.6 ), whereas it persisted for $\mathrm{TN}$ breast cancer even after additional adjustment for poverty level, treatment, and comorbidities (adjusted HR, 2.0; 95\% CI, 1.0 to 3.7) [4]. A second, smaller study followed 124 (88 black, 36 white) women ages 26-82 years with invasive $\mathrm{TN}$ breast cancer treated at the University of Tennessee Cancer Institute, Memphis, between 2003 and 2008 for a median of 23 months [6]. Older black breast cancer patients ( $\geq 55$ years at diagnosis) with TN breast cancer had poorer breast cancerspecific survival than older white women. A third study compared 331 lower income AA women with 203 lower income non-AA women consisting of 115 Hispanic and 88 non-Hispanic white women, who were treated for breast cancer at a large urban public hospital providing care to the medically uninsured in metropolitan Chicago between 2000 and 2005 [7]. This study found that AA women had a higher crude all-cause mortality risk than 


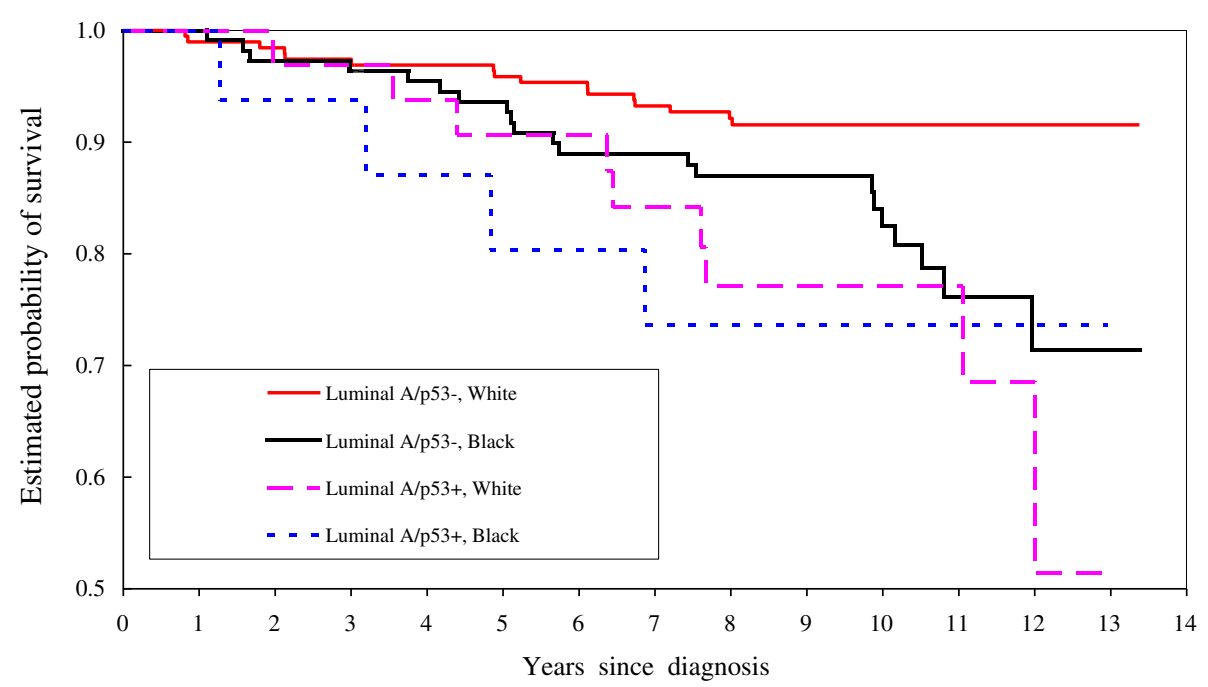

Figure 1 Kaplan-Meier breast cancer-specific survival of older black women vs. older white women diagnosed with luminal A invasive breast cancer sub-typed by $\mathrm{p} 53$.

non-AA women (HR, 1.45 ; $95 \% \mathrm{CI}, 1.03$ to 2.05$)$ irrespective of the subtypes defined by ER, PR, and HER2 status. Results from the Carolina Breast Cancer Study, which followed 1,149 (518 black, 631 white) women with invasive breast cancer from diagnosis between 1993 and 2001 through 2006, are consistent with our results. This study found that the black-white difference in breast cancer-specific mortality was observed for women diagnosed with luminal A breast cancer, but not for those diagnosed with basal-like (ER-/PR-/HER2- plus HER1+ and/or CK 5/6+) breast cancer (age-, date of diagnosis-, and stage at diagnosis-adjusted $\mathrm{HR}, 1.9 ; 95 \% \mathrm{CI}, 1.3$ to 2.9 and HR, 1.3; HR, 0.8 to 2.3 for luminal A and basallike breast cancer, respectively) [5].

An analysis comparing the outcomes of 405 black women with 4,412 nonblack women who had stage I-III breast cancer and who participated in a National Cancer Institute-sponsored randomized phase III trial also provides supporting evidence for our results [51]. Breast cancer-specific and overall survival was lower in black women with luminal A disease than in nonblack women, but no racial differences were observed for women with other subtypes of breast cancer.

Based on our knowledge, this is the first study to examine if the overexpression status of p53 protein impacts the black-white disparities in mortality of $\mathrm{TN}$ or luminal A breast cancer. Our data showed that p53 protein expression status could impact black-white mortality differences, and this was most evident for older women diagnosed with luminal A breast cancer. A possible explanation for no black-white difference in mortality risk for older women with luminal $\mathrm{A} / \mathrm{p} 53+$ tumor is that luminal $\mathrm{A} / \mathrm{p} 53+$ tumor is currently less likely to be treatable for either black women or white women since mutations in $p 53$ are associated with resistance to chemotherapy, radiotherapy, and poor prognosis [31,32]. The reasons for a statistically significantly higher risk in all-cause mortality rather than in breast cancer-specific mortality in older black women diagnosed with luminal A/p53- tumor than their white counterparts, could be related to several adverse factors for overall survival, such as more comorbidities $[7,52]$ and less access to adequate health care because of lower socioeconomic status [53]. The adjustments for all these factors could attenuate the observed black-white difference in allcause mortality risk. Unfortunately, we have data only for potential comorbidities diagnosed prior to breast cancer and for education which can serve as as a rough proxy for social economic status. In our study, the HR for black-white difference in all-cause mortality in older women diagnosed with luminal A/p53- breast cancer decreased from 2.22 (95\% CI, 1.30 to 3.79 ) to 1.64 (0.90 to 3.01) and the HR for black-white difference in breast cancer-specific mortality in older women diagnosed with luminal A/p53- breast cancer decreased from 1.89 (95\% CI, 0.93 to 3.86 ) to 1.50 ( $95 \%$ CI, 0.66 to 3.43 ), after additionally adjusting for the number of comorbidities (zero, one, two or more including hypertension, myocardial infarction, stroke, diabetes, and cancers other than nonmelanoma skin cancers) and education ( $\leq$ high school, technical school/some college, college graduate; results not shown).

This study had several limitations. First, we were unable to request tissue for all eligible women diagnosed with invasive breast cancer in the two study sites because of funding constraints. However, we obtained paraffinembedded tissue for $80 \%$ of the samples requested. Second, we did not have breast cancer treatment information 
Table 3 Adjusted HRs of all-cause mortality associated with race (black women vs. white women)

\begin{tabular}{|c|c|c|c|c|c|c|c|c|}
\hline & \multicolumn{2}{|c|}{ White } & \multicolumn{2}{|c|}{ Black } & \multicolumn{2}{|c|}{ Model $1^{\mathrm{a}}$} & \multicolumn{2}{|c|}{ Model $2^{a, b}$} \\
\hline & Person-years & Death (No.) & Person-years & Death (No.) & $\mathrm{HR}$ & $95 \% \mathrm{Cl}$ & $\mathrm{HR}$ & $95 \% \mathrm{Cl}$ \\
\hline All women & 6246 & 155 & 4471 & 180 & 1.65 & 1.32 to 2.06 & 1.42 & 1.13 to 1.78 \\
\hline \multicolumn{9}{|l|}{ Subtypes defined by ER/PR/HER2 } \\
\hline TN & 1341 & 50 & 1381 & 66 & 1.25 & 0.85 to 1.84 & 1.12 & 0.76 to 1.66 \\
\hline Luminal A & 3853 & 75 & 2235 & 70 & 1.75 & 1.25 to 2.46 & 1.54 & 1.09 to 2.18 \\
\hline Luminal B & 643 & 16 & 481 & 16 & 1.74 & 0.70 to 4.31 & 1.07 & 0.32 to 3.53 \\
\hline HER2-enriched & 408 & 14 & 375 & 28 & 2.69 & 1.06 to 6.85 & 2.41 & 0.90 to 6.40 \\
\hline \multicolumn{9}{|l|}{ Subtypes defined by ER/PR/HER2/p53 } \\
\hline TN/p53- & 825 & 26 & 664 & 34 & 1.45 & 0.82 to 2.54 & 1.38 & 0.77 to 2.49 \\
\hline TN/p53+ & 516 & 24 & 717 & 32 & 1.04 & 0.58 to 1.88 & 1.04 & 0.57 to 1.89 \\
\hline Luminal A/p53- & 3262 & 55 & 1814 & 52 & 1.73 & 1.16 to 2.58 & 1.62 & 1.08 to 2.43 \\
\hline Luminal A/p53+ & 591 & 20 & 421 & 18 & 1.45 & 0.60 to 3.54 & 0.99 & 0.37 to 2.70 \\
\hline Younger women (ages 35-49 yrs) & 3066 & 90 & 2248 & 95 & 1.49 & 1.10 to 2.01 & 1.27 & 0.94 to 1.73 \\
\hline \multicolumn{9}{|l|}{ Subtypes defined by ER/PR/HER2 } \\
\hline TN & 861 & 34 & 785 & 43 & 1.36 & 0.84 to 2.18 & 1.16 & 0.71 to 1.89 \\
\hline Luminal A & 1623 & 36 & 1069 & 28 & 1.33 & 0.79 to 2.23 & 1.20 & 0.71 to 2.03 \\
\hline \multicolumn{9}{|l|}{ Subtypes defined by ER/PR/HER2/p53 } \\
\hline TN/p53- & 513 & 18 & 372 & 21 & 1.44 & 0.72 to 2.87 & 1.43 & 0.70 to 2.90 \\
\hline TN/p53+ & 349 & 16 & 413 & 22 & 1.21 & 0.60 to 2.47 & 1.13 & 0.54 to 2.36 \\
\hline Luminal A/p53- & 1329 & 28 & 792 & 17 & 1.06 & 0.56 to 2.01 & 1.05 & 0.54 to 2.02 \\
\hline Luminal A/p53+ & 294 & 8 & 277 & 11 & 1.32 & 0.32 to 5.42 & 0.92 & 0.21 to 4.06 \\
\hline Older women (ages 50-64 yrs) & 3181 & 65 & 2223 & 85 & 1.89 & 1.36 to 2.62 & 1.62 & 1.17 to 2.26 \\
\hline \multicolumn{9}{|l|}{ Subtypes defined by ER/PR/HER2 } \\
\hline TN & 480 & 16 & 596 & 23 & 1.04 & 0.54 to 2.02 & 1.07 & 0.55 to 2.11 \\
\hline Luminal A & 2231 & 39 & 1167 & 42 & 2.21 & 1.40 to 3.47 & 1.88 & 1.18 to 2.99 \\
\hline \multicolumn{9}{|l|}{ Subtypes defined by ER/PR/HER2/p53 } \\
\hline TN/p53- & 313 & 8 & 292 & 13 & 1.66 & 0.61 to 4.54 & 1.48 & 0.50 to 4.41 \\
\hline TN/p53+ & 167 & 8 & 304 & 10 & 0.77 & 0.27 to 2.20 & 0.79 & 0.27 to 2.30 \\
\hline Luminal A/p53- & 1934 & 27 & 1022 & 35 & 2.49 & 1.47 to 4.22 & 2.22 & 1.30 to 3.79 \\
\hline Luminal A/p53+ & 297 & 12 & 144 & 7 & 1.54 & 0.48 to 4.91 & 1.44 & 0.25 to 8.11 \\
\hline
\end{tabular}

HRs are from multivariable Cox proportional hazards regression models using age (in days) at diagnosis and at death or end of follow-up as the time scale and stratified by single years of age at diagnosis. ${ }^{a}$ Adjusted for study site. ${ }^{b}$ Additionally adjusted for tumor stage. Abbreviations: $\mathrm{HR}$, hazard ratio; $\mathrm{Cl}$, confidence interval. ER, estrogen receptor; PR, progesterone receptor; HER, human epidermal growth factor receptor; TN, triple negative. Note: TN = ER-/PR-/HER2-, Luminal $\mathrm{A}=\mathrm{ER}+$ or PR+ plus HER2-, Luminal B = ER+ or PR+ plus HER2+, HER2-enriched = ER-/PR-/HER2+.

available and therefore did not adjust for treatments in our analyses. Although we have presumed that controlling for age, stage of disease, and the status of the four tumor markers has provided some control for treatment, previous studies have reported that black women may receive less optimal treatment than white women [54-58]. Black women are more likely to delay the initiation of treatment [54], less likely to receive surgery [55] or optimal adjuvant systemic therapy [56], less likely to adhere to recommended treatment regimens [57], and more likely to terminate treatment prematurely [58] than white women. If any black-white differences in treatment existed in our participants, the HRs for a black-white difference in mortality risk could be overestimated, but it is unlikely that this bias would differ across tumor subtypes. Third, although our HRs for a black-white difference in both breast cancerspecific and all-cause mortality suggest that a large blackwhite difference in mortality risk may exist in women diagnosed with HER2-enriched tumors, the number of deaths was limited for this analysis. Fourth, due to funding limitations, we evaluated p53 protein expression, but not $p 53$ mutations. Although previous research shows that p53 protein expression and $p 53$ mutation status determined by FISH analysis are strongly correlated, our assessment of p53 protein expression by IHC may have misclassified some tumors. Fifth, although the agreement in the 
classification for ER and PR status between the SEER registry and centralized laboratory was substantial [59], we repeated the analyses for $\mathrm{TN}$ and luminal $\mathrm{A}$ and their subtypes defined by p53 status using ER/PR status from SEER instead of those from the centralized laboratory for the 918 women who had both ER and PR expression status in SEER; we obtained similar results (data not shown). Finally, our study provides evidence suggesting that blackwhite differences in mortality vary by tumor subtypes among older women. However, the number of deaths among older black women with TN subtype was small resulting in limited statistical power to detect statistically significant difference in race-specific HRs between luminal $A$ and TN breast cancer. The number of deaths among older black women with luminal A/p53+ subtype was also small resulting in limited statistical power to detect significant difference in race-specific HRs between luminal A/ p53- and luminal A/p53+ subtype. Therefore, confirmation of our results will require larger studies to demonstrate statistically meaningful differences.

\section{Conclusions}

Our findings suggest that the black-white difference in mortality risk is mainly among women 50 years or older diagnosed with luminal A/p53- breast cancer, a subtype for which treatments exist. These results further suggest that factors other than subtype may be relatively more important in explaining the increased mortality risk seen in older black women.

\section{Abbreviations \\ AA: African American; BMI: Body mass index; ER: Estrogen receptor; PR: Progesterone receptor; HER: Human epidermal growth factor receptor; TN: Triple negative; CARE: Contraceptive and reproductive experiences; LA: Los Angeles; IHC: Immunohistochemistry; FISH: Fluorescent in situ hybridization; HR: Hazard ratio; Cl: Confidence interval.}

\section{Competing interests}

The authors declare that they have no competing interests.

\section{Authors' contributions}

$\mathrm{RS}, \mathrm{DMD}, \mathrm{BLS}$, and LB participated in the study design and supervised the collection and assembly of data. KEM, PAM, RTB, JAM, SGF, and JS supervised or participated in the collection and assembly of data. HM conducted data analyses and drafted the manuscript with LB's input. All authors participated in the revision of the manuscript and have read and approved the final version.

\section{Acknowledgments}

This work was supported by National Institute for Child Health and Human Development grant NO1-HD-3-3175 and National Cancer Institute grant K05CA136967. Data collection for the Women's CARE Study was supported by the National Institute of Child Health and Human Development and National Cancer Institute, NIH, through contracts with Emory University (N01-HD-33168), Fred Hutchinson Cancer Research Center (N01-HD-2-3166), Karmanos Cancer Institute at Wayne State University (N01-HD-3-3174), University of Pennsylvania (NO1-HD-3-3276), and University of Southern California (N01HD-3-3175) and Interagency Agreement with Centers for Disease Control and Prevention (Y01-HD-7022). Collection of cancer incidence data in LA County by University of Southern California was supported by California Department of Health Services as part of statewide cancer reporting program mandated by California Health and Safety Code, Section 103885. Support for use of SEER cancer registries through contracts N01-CN-65064
(Detroit) and N01-PC-67010 (LA). Biomarker determination and analyses were supported by a contract from the National Institute of Child Health and Human Development (NO1-HD-3-3175) and a grant from the Breast Cancer Research Foundation (MFPress).

The findings and conclusions in this report are those of the authors and do not necessarily represent the official position of the Centers for Disease Control and Prevention. Authors thank Dr. Karen Petrosyan, Armine Arakelyan, Hasmik Toumaian, and Judith Udove for technical assistance in the performance of the immunohistochemical assays for this study and the collaborators who contributed to the development and conduct of the Women's CARE Study but who did not directly contribute to the current study.

\section{Author details}

'Division of Cancer Etiology, Department of Population Sciences, Beckman Research Institute, City of Hope, Duarte, CA 91010, USA. 'Division of Public Health Sciences, Fred Hutchinson Cancer Research Center, Seattle, WA 98109, USA. ${ }^{3}$ Division of Reproductive Health, Centers for Disease Control and Prevention, Atlanta, GA 30333, USA. ํDepartment of Preventive Medicine, University of Southern California, Los Angeles, CA 90033, USA. ${ }^{5}$ Pathology, Keck School of Medicine, University of Southern California, Los Angeles, CA 90033, USA. ${ }^{6}$ Formerly Contraceptive and Reproductive Health Branch, Center for Population Research, National Institute of Child Health and Development, Bethesda, MD 20892, USA. ${ }^{7}$ Department of Obstetrics and Gynecology, Baystate Medical Center, Springfield, MA 01199, USA. ${ }^{8}$ Center for Clinical Epidemiology and Biostatistics, Department of Biostatistics and Epidemiology, University of Pennsylvania School of Medicine, Philadelphia, PA 19104, USA. ${ }^{9}$ Karmanos Cancer Institute, Department of Oncology, Wayne State University, Detroit, MI 48201, USA.

\section{Received: 22 October 2012 Accepted: 1 May 2013}

Published: 4 May 2013

\section{References}

1. Jatoi I, Anderson WF, Rao SR, Devesa SS: Breast cancer trends among black and white women in the United States. J Clin Oncol 2005, 23(31):7836-7841.

2. U.S. Mortality Files NCfHS, CDC: Female breast cancer death rates by race and ethnicity, U.S., 1999-2009. 2012. http://www.cdc.gov/cancer/breast/statistics/ race.htm.

3. Carey LA, Perou CM, Livasy CA, Dressler LG, Cowan D, Conway K, Karaca G, Troester MA, Tse CK, Edmiston S, et al: Race, Breast Cancer Subtypes, and Survival in the Carolina Breast Cancer Study. JAMA 2006, 295(21):2492-2502.

4. Lund MJ, Trivers KF, Porter PL, Coates RJ, Leyland-Jones B, Brawley OW, Flagg EW, O'Regan RM, Gabram SG, Eley JW: Race and triple negative threats to breast cancer survival: a population-based study in Atlanta, GA. Breast Cancer Res Treat 2009, 113(2):357-370.

5. O'Brien KM, Cole SR, Tse CK, Perou CM, Carey LA, Foulkes WD, Dressler LG, Geradts J, Millikan RC: Intrinsic breast tumor subtypes, race, and longterm survival in the Carolina Breast Cancer Study. Clin Cancer Res 2010, 16(24):6100-6110.

6. Sachdev JC, Ahmed S, Mirza MM, Farooq A, Kronish L, Jahanzeb M: Does race affect outcomes in triple negative breast cancer? Breast Cancer (Auckl) 2010, 4:23-33.

7. Dookeran KA, Dignam JJ, Holloway N, Ferrer K, Sekosan M, McCaskillStevens W, Gehlert S: Race and the prognostic influence of p53 in women with breast cancer. Ann Surg Oncol 2012, 19(7):2334-2344.

8. Bauer KR, Brown M, Cress RD, Parise CA, Caggiano V: Descriptive analysis of estrogen receptor (ER)-negative, progesterone receptor (PR)-negative, and HER2-negative invasive breast cancer, the so-called triple-negative phenotype: a population-based study from the California cancer Registry. Cancer 2007, 109(9):1721-1728.

9. Carey LA, Dees EC, Sawyer L, Gatti L, Moore DT, Collichio F, Ollila DW, Sartor $\mathrm{Cl}$, Graham ML, Perou CM: The triple negative paradox: primary tumor chemosensitivity of breast cancer subtypes. Clin Cancer Res 2007, 13(8):2329-2334.

10. Dent R, Trudeau M, Pritchard Kl, Hanna WM, Kahn HK, Sawka CA, Lickley LA, Rawlinson E, Sun P, Narod SA: Triple-negative breast cancer: clinical features and patterns of recurrence. Clin Cancer Res 2007, 13(15 Pt 1):4429-4434.

11. Ma H, Luo J, Press MF, Wang Y, Bernstein L, Ursin G: Is there a difference in the association between percent mammographic density and subtypes of breast cancer? Luminal A and triple-negative breast cancer. Cancer Epidemiol Biomarkers Prev 2009, 18(2):479-485. 
12. Ma H, Wang $Y$, Sullivan-Halley J, Weiss L, Marchbanks PA, Spirtas R, Ursin G, Burkman RT, Simon MS, Malone KE, et al: Use of four biomarkers to evaluate the risk of breast cancer subtypes in the women's contraceptive and reproductive experiences study. Cancer Res 2010, 70(2):575-587.

13. Onitilo AA, Engel JM, Greenlee RT, Mukesh BN: Breast cancer subtypes based on ER/PR and Her2 expression: comparison of clinicopathologic features and survival. Clin Med Res 2009, 7(1-2):4-13.

14. Phipps Al, Malone KE, Porter PL, Daling JR, Li Cl: Reproductive and hormonal risk factors for postmenopausal luminal, HER-2-overexpressing, and triple-negative breast cancer. Cancer 2008, 113(7):1521-1526.

15. Yang XR, Chang-Claude J, Goode EL, Couch FJ, Nevanlinna H, Milne RL, Gaudet M, Schmidt MK, Broeks A, Cox A, et al: Associations of breast cancer risk factors with tumor subtypes: a pooled analysis from the Breast Cancer Association Consortium studies. J Natl Cancer Inst 2011, 103(3):250-263.

16. Yang XR, Sherman ME, Rimm DL, Lissowska J, Brinton LA, Peplonska B, Hewitt SM, Anderson WF, Szeszenia-Dabrowska N, Bardin-Mikolajczak A, et al: Differences in risk factors for breast cancer molecular subtypes in a population-based study. Cancer Epidemiol Biomarkers Prev 2007, 16(3):439-443.

17. Anders CK, Carey LA: Biology, metastatic patterns, and treatment of patients with triple-negative breast cancer. Clin Breast Cancer 2009, 9(Suppl 2):S73-S81.

18. Kreike $B$, van Kouwenhove $M$, Horlings $H$, Weigelt $B$, Peterse $H$, Bartelink $H$, van de Vijver MJ: Gene expression profiling and histopathological characterization of triple-negative/basal-like breast carcinomas. Breast Cancer Res 2007, 9(5):R65.

19. Perou CM: Molecular stratification of triple-negative breast cancers. Oncologist 2011, 16(Suppl 1):61-70.

20. Schneider BP, Winer EP, Foulkes WD, Garber J, Perou CM, Richardson A, Sledge GW, Carey LA: Triple-negative breast cancer: risk factors to potential targets. Clin Cancer Res 2008, 14(24):8010-8018.

21. Hudis CA, Gianni L: Triple-negative breast cancer: an unmet medical need. Oncologist 2011, 16(Suppl 1):1-11

22. Millikan RC, Newman B, Tse CK, Moorman PG, Conway K, Smith LV, Labbok $\mathrm{MH}$, Geradts J, Bensen JT, Jackson S, et al: Epidemiology of basal-like breast cancer. Breast Cancer Res Treat 2008, 109:123-139.

23. Kwan ML, Kushi LH, Weltzien E, Maring B, Kutner SE, Fulton RS, Lee MM, Ambrosone CB, Caan BJ: Epidemiology of breast cancer subtypes in two prospective cohort studies of breast cancer survivors. Breast Cancer Res 2009, 11(3):R31.

24. Trivers KF, Lund MJ, Porter PL, Liff JM, Flagg EW, Coates RJ, Eley JW: The epidemiology of triple-negative breast cancer, including race. Cancer Causes Control 2009, 20:1071-1082.

25. Baker SJ, Fearon ER, Nigro JM, Hamilton SR, Preisinger AC, Jessup JM, VanTuinen $\mathrm{P}$, Ledbetter DH, Barker DF, Nakamura Y, et al: Chromosome 17 deletions and p53 gene mutations in colorectal carcinomas. Science 1989, 244(4901):217-221.

26. Lane DP, Benchimol S: p53: oncogene or anti-oncogene? Genes Dev 1990 4(1):1-8

27. Gasparini G, Pozza F, Harris AL: Evaluating the potential usefulness of new prognostic and predictive indicators in node-negative breast cancer patients. J Natl Cancer Inst 1993, 85(15):1206-1219.

28. Davidoff AM, Humphrey PA, Iglehart JD, Marks JR: Genetic basis for p53 overexpression in human breast cancer. Proc Natl Acad Sci U S A 1991, 88(11):5006-5010.

29. Allred DC, Elledge R, Clark GM, Fuqua SA: The p53 tumor-suppressor gene in human breast cancer. Cancer Treat Res 1994, 71:63-77.

30. Smith HS: Tumor-suppressor genes in breast cancer progression. Cancer Treat Res 1994, 71:79-96

31. Pirollo KF, Bouker KB, Chang EH: Does p53 status influence tumor response to anticancer therapies? Anticancer Drugs 2000, 11(6):419-432.

32. Pharoah PD, Day NE, Caldas C: Somatic mutations in the $p 53$ gene and prognosis in breast cancer: a meta-analysis. Br J Cancer 1999, 80(12):1968-1973.

33. Hill KA, Sommer SS: p53 as a mutagen test in breast cancer. Environ Mol Mutagen 2002, 39(2-3):216-227.

34. Rossner P Jr, Gammon MD, Zhang YJ, Terry MB, Hibshoosh H, Memeo L, Mansukhani M, Long CM, Garbowski G, Agrawal M, et al: Mutations in p53, p53 protein overexpression and breast cancer survival. J Cell Mol Med 2009, 13(9B):3847-3857.

35. Rakha EA, El-Sayed ME, Green AR, Lee AH, Robertson JF, Ellis IO: Prognostic markers in triple-negative breast cancer. Cancer 2007, 109(1):25-32.
36. Lukas J, Niu N, Press MF: p53 mutations and expression in breast carcinoma in situ. Am J Pathol 2000, 156(1):183-191.

37. Wen WH, Reles A, Runnebaum IB, Sullivan-Halley J, Bernstein L, Jones LA Felix JC, Kreienberg R, el-Naggar A, Press MF: p53 mutations and expression in ovarian cancers: correlation with overall survival. Int $J$ Gynecol Pathol 1999, 18(1):29-41.

38. Lu Y, Ma H, Malone KE, Norman SA, Sullivan-Halley J, Strom BL, Marchbanks PA, Spirtas R, Burkman RT, Deapen D, et al: Obesity and survival among black women and white women 35 to 64 years of age at diagnosis with invasive breast cancer. J Clin Oncol 2011, 29(25):3358-3365.

39. Marchbanks PA, McDonald JA, Wilson HG, Burnett NM, Daling JR, Bernstein L, Malone KE, Strom BL, Norman SA, Weiss LK, et al: The NICHD Women's Contraceptive and Reproductive Experiences Study: methods and operational results. Ann Epidemiol 2002, 12(4):213-221.

40. Press MF, Greene GL: An immunocytochemical method for demonstrating estrogen receptor in human uterus using monoclonal antibodies to human estrophilin. Lab Invest 1984, 50(4):480-486.

41. Press M, Spaulding B, Groshen S, Kaminsky D, Hagerty M, Sherman L, Christensen K, Edwards DP: Comparison of different antibodies for detection of progesterone receptor in breast cancer. Steroids 2002, 67(9):799-813.

42. Hammond ME, Hayes DF, Dowsett M, Allred DC, Hagerty KL, Badve S, Fitzgibbons PL, Francis G, Goldstein NS, Hayes M, et al: American Society of Clinical Oncology/College of American Pathologists guideline recommendations for immunohistochemical testing of estrogen and progesterone receptors in breast cancer (unabridged version). Arch Pathol Lab Med 2010, 134(7):e48-e72.

43. Press MF, Sauter G, Bernstein L, Villalobos IE, Mirlacher M, Zhou J-Y, Wardeh R, Li Y-T, Guzman R, Ma Y, et al: Diagnostic evaluation of HER-2 as a molecular target: an assessment of accuracy and reproducibility of laboratory testing in large, prospective, randomized clinical trials. Clin Cancer Res 2005, 11(18):6598-6607.

44. Press MF, Slamon DJ, Flom KJ, Park J, Zhou J-Y, Bernstein L: Evaluation of HER-2/neu Gene Amplification and Overexpression: Comparison of Frequently Used Assay Methods in a Molecularly Characterized Cohort of Breast Cancer Specimens. J Clin Oncol 2002, 20(14):3095-3105.

45. Saffari B, Bernstein L, Hong DC, Sullivan-Halley J, Runnebaum IB, Grill HJ, Jones LA, El-Naggar A, Press MF: Association of p53 mutations and a codon 72 single nucleotide polymorphism with lower overall survival and responsiveness to adjuvant radiotherapy in endometrioid endometrial carcinomas. Int J Gynecol Cancer 2005, 15(5):952-963.

46. Schmider A, Gee C, Friedmann W, Lukas JJ, Press MF, Lichtenegger W, Reles A: p21 (WAF1/CIP1) protein expression is associated with prolonged survival but not with p53 expression in epithelial ovarian carcinoma. Gynecol Oncol 2000, 77(2):237-242.

47. Cox D, Oakes D: Analysis of survival data. London, England: Chapman \& Hall; 1984

48. Rothman KJ, Greenland S: Modern epidemiology. Philadelphia: LippincottRaven; 1998

49. Allison P: Survival Analysis Using SAS๑: A Practical Guide Second Edition. 2nd edition. Cary, NC: SAS Institute Inc.; 2010.

50. $\mathrm{Li} \mathrm{Cl}$, Malone KE, Daling JR: Differences in breast cancer stage, treatment and survival by race and ethnicity. Arch Intern Med 2003, 163(1):49-56.

51. Sparano JA, Wang M, Zhao F, Stearns V, Martino S, Ligibel JA, Perez EA, Saphner T, Wolff AC, Sledge GW Jr, et al: Race and hormone receptorpositive breast cancer outcomes in a randomized chemotherapy trial. J Natl Cancer Inst 2012, 104(5):406-414.

52. Tammemagi CM, Nerenz D, Neslund-Dudas C, Feldkamp C, Nathanson D: Comorbidity and survival disparities among black and white patients with breast cancer. JAMA 2005, 294(14):1765-1772.

53. Bassett MT, Krieger N: Social class and black-white differences in breast cancer survival. Am J Public Health 1986, 76(12):1400-1403.

54. Gorin SS, Heck JE, Cheng B, Smith SJ: Delays in breast cancer diagnosis and treatment by racial/ethnic group. Arch Intern Med 2006, 166(20):2244-2252

55. Bradley CJ, Given CW, Roberts C: Race, socioeconomic status, and breast cancer treatment and survival. J Natl Cancer Inst 2002, 94(7):490-496.

56. Jatoi I, Becher $\mathrm{H}$, Leake CR: Widening disparity in survival between white and African-American patients with breast carcinoma treated in the US Department of Defense Healthcare system. Cancer 2003, 98(5):894-899.

57. Griggs JJ, Sorbero ME, Stark AT, Heininger SE, Dick AW: Racial disparity in the dose and dose intensity of breast cancer adjuvant chemotherapy. Breast Cancer Res Treat 2003, 81(1):21-31. 
58. Hershman D, McBride R, Jacobson JS, Lamerato L, Roberts K, Grann VR, Neugut Al: Racial disparities in treatment and survival among women with early-stage breast cancer. J Clin Oncol 2005, 23(27):6639-6646.

59. Ma H, Wang Y, Sullivan-Halley J, Weiss L, Burkman RT, Simon MS, Malone KE, Strom BL, Ursin G, Marchbanks PA, et al: Breast cancer receptor status: do results from a centralized pathology laboratory agree with SEER registry reports? Cancer Epidemiol Biomarkers Prev 2009, 18(8):2214-2220.

doi:10.1186/1471-2407-13-225

Cite this article as: Ma et al:: Mortality risk of black women and white women with invasive breast cancer by hormone receptors, HER2, and p53 status. BMC Cancer 2013 13:225.

\section{Submit your next manuscript to BioMed Central and take full advantage of:}

- Convenient online submission

- Thorough peer review

- No space constraints or color figure charges

- Immediate publication on acceptance

- Inclusion in PubMed, CAS, Scopus and Google Scholar

- Research which is freely available for redistribution 